\title{
Psychiatric patients' satisfaction in the therapeutic residence services: A positive experience of psychiatric deinstitutionalization
}

Rafael Gustavo Maluf. Universidade José do Rosário Vellano

Marina de Bittencourt Bandeira. Universidade Federal de São João Del Rei

Daniela Carine Ramires de Oliveira. Universidade Federal de São João Del Rei

\begin{abstract}
This study investigated the satisfaction level of psychiatric patients in the therapeutic residential services of Barbacena-MG. Total population comprised 154 individuals, of which 45 were sampled. Subjects were interviewed with the SATIS-BR scale and a sociodemographic questionnaire. Results showed a high degree of satisfaction with the service for the global score and its three dimensions staff competence and understanding, help received, infrastructure. Results were not related to sociodemographic and clinical variables analyzed individually. Multivariate analysis indicated higher satisfaction for literate patients and for those that underwent some other form of treatment (e.g., hydrogymnastics and fitness activities) besides medications or occupational therapy. We conclude that the therapeutic residence services appear to be a viable alternative for mental health public policy, from the patients' perspective.
\end{abstract}

Keywords: therapeutical residence; patient satisfaction; community service; mental disturbance; mental health.

\section{Resumo}

Satisfação dos pacientes psiquiátricos nos serviços residenciais terapêuticos: Uma experiência positiva de desintitucionalização psiquiátrica. O estudo objetivou avaliar a satisfação dos pacientes psiquiátricos nos Serviços Residenciais Terapêuticos-SRTs de Barbacena-MG. A população era de 154 indivíduos, dos quais 45 compuseram a amostra estudada. Os sujeitos foram entrevistados com aplicação da escala SATIS-BR. Os resultados indicaram alto grau de satisfação com os serviços, globalmente e nas dimensões competência e compreensão da equipe, acolhida e ajuda recebida, e infraestrutura. $O$ grau de satisfação foi independente da maioria das características sociodemográficas ou clínicas dos sujeitos, quando analisadas isoladamente. Análise multivariada indicou maior satisfação para pacientes alfabetizados e que faziam algum tipo de tratamento (e.g. hidroginástica e atividades físicas), além do medicamentoso e da terapia ocupacional. Conclui-se que os SRTs são uma alternativa viável de política de saúde mental, sob a perspectiva dos moradores.

Palavras-chave: residência terapêutica; satisfação do paciente; serviço comunitário; transtorno mental; saúde mental.

\section{Resumen}

Satisfacción de pacientes psiquiátricos con los servicios residenciales terapéuticos: Una experiencia positiva de desinstitucionalización psiquiátrica. El objetivo de este estudio fue evaluar la satisfacción de pacientes psiquiátricos en Servicios Terapéuticos Residenciales-SRT de Barbacena-MG. La población fue de 154 personas, de las cuales 45 fueron escogidos para ser evaluados. Los sujetos fueron entrevistados utilizando la Escala de Satisfacción de Servicios de Salud Mental-SATIS-BR. Los resultados indicaron alto grado de satisfacción con los servicios prestados en la escala global y en sus dimensiones competencia y conocimiento de equipo, bienvenida y asistencia recibidas, y infraestructura. El alto grado de satisfacción fue independiente de la mayoría de las características sociodemográficas o clínicas, cuando se analizaron por separado. Análisis multivariado indicó mayor satisfacción para los pacientes que saben leer y escribir, así como aquellos que hacen algún otro tipo de tratamiento (e.g. hidroginástica y actividades físicas), que no sea la droga o terapia ocupacional. En conclusión, los SRT son una política de salud mental alternativa viable, desde el punto de vista de sus residentes.

Palabras clave: viviendas terapéuticas; satisfacción del paciente; servicios comunitarios; transtorno mental; salud mental. 
Mental health services have been changing substantially in the last decades around the world (Thornicroft \& Tansella, 2010). From 1950 and beyond a gradual shift was made from the asylum/hospital models of mental health services towards the communitybased services that are close to patients' home, the so-called psychiatric deinstitutionalization (Jaegger et al., 2004). In Brazil, the initial steps toward the psychiatric reform date back to the 1970 decade, when the Brazilian movement for sanitary reform was implemented. Psychiatric deinstitutionalization is a complex social and political process that covers a multitude of actors, institutions and sources: federal, state and county governments, universities, health care providers, professional councils, patients' associations, and family members (Delgado et al., 2007). In Brazil, the health care workers movement in the late 1970's denounced violence against patients in psychiatric hospitals, as well as the prevalence of a private profit-based rather than a public network of mental health services (Delgado et al., 2007). The years after 1980 marked the establishment of the first Center for Psychosocial Care ("Centro de Atenção Psicossocial" - CAPS) in the city of São Paulo, as well as the establishment of cooperatives, associations and residences for patients formerly in psychiatric hospitals (Delgado et al., 2007). A bill regulating psychiatric patients' rights and calling for gradual extinction of psychiatric hospitals was proposed in 1989 before the Brazilian Congress, and made into law through the 10.216/2001 Act. This act, passed in 2001, redirected mental health services towards community-based services, and established rights and protection to mental health patients. Psychiatric deinstitutionalization thus became a matter of public policy, whereby alternative community-based mental health services should be emphasized. Programs were created that established the basis for a planned steady decrease in hospitalbased mental care (Furtado, 2006).From 2002-2005, a decrease of 6227 mental hospital beds was recorded nationwide (Delgado et al., 2007). In contrast, the number of community-based mental services has increased steadily (Andreoli, 2007).

Psychiatric deinstitutionalization in Brazil established community-based mental health programs and services, such as the Family Health Program ("Programa Saúde da Família" - PSF), the Coming Back Home Program ("Programa de Volta para Casa" - PVC), the Centers for Psychosocial Care ("Centros de Atenção Psicossocial" - CAPS), and the Therapeutical Residence
Services ("Serviços Residenciais Terapêuticos" - SRT). PSF is focused on the care of physical health, as well as on health education and disease prevention, but its agents may also attend people with mental health problems. PVC provides monthly cash stipends (less than one minimum wage) to patients released from psychiatric hospital after one or more years of continual hospitalization. The CAPS provide psychiatric patients with clinical assistance on a daily basis, with the purpose of avoiding hospitalization and promoting their social insertion. This service also provides mental health supervision by professionals of the general basic health system (Delgado et al., 2007). Psychiatric patients may be eligible also for social care programs, such as the Social Assistance Benefit ("Benefício de Prestação Continuada da Assistência Social" (BPC) - that provides a minimum wage income to senior citizens (age $>=65$ ) or to handicapped people (of any age) with long-time physical or psychological impediments (Ministério do Desenvolvimento Social e Combate à Fome, 2014).

The Therapeutical Residence Services (SRT) are mental health services mainly designed to provide for the needs of psychiatric patients who were long term hospital internees. Even though the SRT residences are considered health facilities, they are nonetheless supposed to grant patients' rights to housing and help patients in their reinsertion in the community (Delgado et al., 2007). Each residence should be assisted by a mental health professional staff, including caregivers and nursing professionals. The SRT are services that are rather recent in Brazil, but are steadily increasing: between 2002 and 2011, their numbers rose from 85 to 625 (Ministério da Saúde, 2004).

Cities or counties such as Barbacena, in the State of Minas Gerais (MG), with long tradition of psychiatric hospitals (Vidal, Bandeira, \& Gontijo, 2008), were among the first to adopt the alternative SRT model. Barbacena at one time had seven large psychiatric hospitals, all of which had difficulty in offering adequate treatment to patients. The city established its first therapeutical residence in 2000, and soon became a national reference in the SRT model (Vidal et al., 2008), with 28 residences and over 150 patients in 2014.

In order to improve the quality of care, mental health services should be monitored, as recommended by the World Health Organization (WHO). This organization also suggested the use of quality indicators and increased support for research in this area (WHO, 1996). Authors have generally agreed as to the need for

Estudos de Psicologia, 22(3), julho a setembro de 2017, 274-284 
evaluation of mental health services (Contandriopoulos, 2006; Donabedian, 1966; Donabedian, 1990) and recognized the importance of including the patients' perspective in this evaluation (Thornicroft \& Tansella, 2005). Patients' satisfaction is currently regarded as one of the best indicative parameters of the quality of health services (Ruggeri, 2010). Satisfaction has been considered a result of patients' subjective expectations, attitudes towards life, self-esteem, behavior regarding diseases and previous experience with health services, and can also influence their adherence to treatment and the frequency of utilization of services (Ruggeri, 1994; Ruggeri, 2010).

Patients' satisfaction with therapeutic residences has been evaluated in several countries (Greenfield, Stoneking, Humphreys, Sundby, \& Bond, 2008; Hanrahan, Luchins, Savage \& Goldman, 2001; Hawthorne et al., 2005; Hawthorne, Green, Lohr, Hough, \& Smith, 1999; Kasprow, Frisman, \& Rosenheck, 1999; Osborn et al., 2010; Piat et al., 2008) through the use of validated rating scales. In Brazil, several studies have evaluated patients' satisfaction with mental health services (Bandeira \& Silva, 2012; Bandeira, Silva, Camilo, \& Felicio, 2011; Camilo, Bandeira, Leal, \& Scalon, 2012; Heckert, Teixeira, \& Trindade, 2007; Kantorski et al., 2009; Silva, Bandeira, Scalon, \& Quaglia, 2012) but they have focused on the non-residential mental health service CAPS. Only in one case (Jaegger et al., 2004) did the study aim to assess patients' satisfaction in a residential service, SRT. The results of this study showed that $86,6 \%$ of the patients declared themselves fully satisfied with the services. However, these conclusions, based on data from only one institution (Instituto Julio Moreira, in Rio de Janeiro) may not be applicable to other SRTs, and, furthermore, they comprised a limited patient sample (15 patients). Therefore, there is a need to develop more research on the patients' evaluation of residential services. The present study aimed to assess patients' satisfaction and its associated factors in the therapeutic residences (SRTs) of the city of Barbacena-MG. Those services were chosen for evaluation because they are situated in a city with a unique past history of psychiatric hospitalization, and because it was one of the first cities to establish the SRT program.

\section{Method}

\section{Target Population}

The target population comprised 154 psychiatric patients from 25 residence services units (SRT), in the city of Barbacena-MG, Brazil. Each residence harbored at most ten patients. Residents were adults with serious and persistent psychiatric disorders, with precarious or non-existent family ties. The Barbacena residence services are part of a countywide network of health services which include other types of mental health services. Each residence is associated to a reference service unit (CAPS) that provides medication and assistance to its patients. Inclusion criteria for the target population were: age 18 or older, from both sexes. Patients who were not able to understand the questions asked during the interviews.

\section{Sample Size}

A non-random sample of patients was selected in the services among those who were available and agreeing to be interviewed. Sample size was previously calculated in order to achieve a type II error of $10 \%$, admitting a sample power of $d=|d| / s=0,5$, where: $\mathrm{d}=0.5$ (established by the authors of this study) and $\mathrm{s}=1$ (an overestimation of values obtained in previous satisfaction studies) (Bandeira, Ishara, \& Zuardi, 2007; Jaegger et al., 2004; Silva et al., 2012). The necessary sample size was calculated as 44 . Four patients were previously excluded from the study for not being able to understand the questions that were asked. Altogether, 45 patients were chosen that fulfilled the inclusion criteria indicated.

\section{Assessment of Patients' Satisfaction}

Patients' satisfaction was assessed through the use of the SATIS-BR scale, a validated instrument (Bandeira \& Silva, 2012) for the evaluation of satisfaction with mental health services. The questionnaire that gave rise to this scale is based on a 19-country study originally conducted by the WHO (1996). The scale validation for the Brazilian context was conducted by the Mental Health Research Laboratory (LAPSAM) at the Universidade Federal de São João del-Rei (UFSJ) (Bandeira \& Silva, 2012; Bandeira, Pitta, \& Mercier, 2000). The SATIS-BR scale comprises 12 questions, distributed among three sub-scales: Subscale 1 includes seven questions assessing patients' satisfaction with the caregivers' competence and understanding of their problems. Subscale 2 has three questions which evaluate patients' satisfaction with the way they were treated and helped in the service. Subscale 3 includes two questions related to patients' satisfaction with the physical settings and general comfort provided by the 
service. Response options are presented as a 5-point Likert scale, in which 1 indicates full dissatisfaction, and 5 indicates full satisfaction with the services.

\section{Sociodemographic and Clinical Questionnaire}

A sociodemographic and clinical questionnaire, previously developed and tested at the LAPSAM/UFSJ (Barroso, Bandeira, \& Nascimento, 2007), was applied to the interviewees, in order to assess their sociodemographic \& life conditions, and clinical variables. The questionnaire evaluates the following sociodemographic variables and patient life conditions: age, sex, marital status, education, income, number of persons in his/her residence, among others. Clinical variables evaluated were: diagnostic, comorbidity, number of years in psychiatric treatment, type of treatment, length of the last psychiatric hospital stay, numbers and types of medication taken.

\section{Data Analyse}

Patients' responses to the SATIS-BR instrument were tabulated as a function of the sociodemographic or clinical variables evaluated by the questionnaire. Descriptive statistics (means, standard deviations and frequency of responses) were obtained for each of the 12 questions in the SATIS-BR scale (Table 1). KruskalWallis tests and multiple comparisons were performed to compare the SATIS-BR three subscales (Table 2).

Mann-Whitney two-sample tests were also performed for comparisons of SATIS-BR scores between levels of the categorical variables evaluated by the sociodemographical and clinical questionnaires (Table 3). Spearman correlations coefficients were calculated between SATIS-BR scores and the levels of the continuous variables of the questionnaire (Table 4).

In order to identify groups of sociodemographic or clinical variables that could be predictors of SRT residents' satisfaction, a stepwise procedure for multiple linear regressions was used. Only independent variables identified as significant $(p<0.05)$ and those identified as non-significant with $(p<0.25)$ were included in the initial stepwise procedures. For the stepwise procedure, the values of $(p=0.15)$ and $(p=0.20)$ were adopted, respectively, as input and output probability criteria (Table 5). Statistical analysis and procedures were performed with the use of the software SPSS, version 20.0.

\section{Data Collection and Ethical Considerations}

SRT officials were initially contacted by the first author in order to explain the objectives of the study and the procedures to be deployed. The importance of evaluation of patients' satisfaction was pointed to these officials. The project proposal was submitted to and approved by our University Ethics Committee for Research with Human Beings, as well as by the Barbacena-MG Coordination of the SRT program.

Patient's participation was voluntary and they were interviewed only after they had signed a Consent Form, declaring to be informed of the objectives and procedures of the research, and that they agreed to participate in the survey. A copy of the consent form, signed also by the researcher, was given to each of the patients interviewed, along with a phone number for direct contact with the research team. The interviewer informed the patients that they could use the phone number to inquire about the research, to clarify any possible doubts they could have, or to withdraw their consent to participate in the interview.

The objectives and procedures to be followed, and the estimated length of the interview, were previously informed to all participants in the survey. Participants were informed that they could quit the interview at any time they wished, and that no consequences would arise from this decision. They were also informed that their participation in the interview would not interfere in any way either in their permanence in the residence or in the treatment they received in the CAPS. Participants were likewise informed that there was no right or wrong answer, that they should answer to the questions sincerely, and that their answers would remain secret and anonymous. The SATIS-BR instrument was applied, always by the same interviewer, in individual interviews with each of the 45 patients sampled, conducted from May through September 2014.

\section{Results}

\section{Sample Description}

Out of the 45 SRT residents in the survey, 53.33\% were females and $46.66 \%$ males. Mean patient age was 59.35 years, with a range between 39 and 97 . The overwhelming majority of patients (84.44\%) were single, whereas $11.11 \%$ lived with a companion or spouse. Illiteracy was declared by $40.00 \%$ of them, whereas $44.00 \%$ were barely literate, and only $13.33 \%$ had completed high school. Out of 45 patients interviewed, 44 (or $97.77 \%$ ) had at least one source of income, and $42.22 \%$ declared two sources of income, those of the governmental programs PVC and BPC. An overwhelming majority (93.33\%) did not have any formal jobs. 
A large majority of patients (91.11\%) attended out-of-home activities such as literacy programs, art therapy or hydrotherapy. In-house activities such as general home cleaning or help in the kitchen were reported by $97.77 \%$ of the residents. Over two-thirds of the patients (68.89\%) did not have individual bedrooms and $57.77 \%$ shared room with only one additional person, whereas $11.11 \%$ shared a bedroom with two additional people.

Results of the clinical survey indicated that in $66.66 \%$ of the cases information on diagnostic category could not be retrieved from patients' files in the Barbacena Coordination Center for mental health, but $20 \%$ of the cases indicated diagnostics in the category "Schizophrenia, Schizotypal Disorders and Delusional Disorders", according to the International Classification of Diseases of the World Health Organization (CID-10) (Organização Mundial de Saúde, 1998). The majority of residents (82.22\%) showed no physical comorbidities. Patients' mean time undergoing psychiatric treatment was 29.53 years (standard deviation $=16.56$ years). All patients interviewed had undergone long stays at psychiatric hospitals, with a mean period of 23.5 years for the last hospitalization.

All interviewees underwent psychological treatment, $91.11 \%$ had medication treatment and over 50\% underwent also other types of treatment, which included hydrogymnastics and fitness activities (60\% had three and $6.66 \%$ four types of treatment). The mean number of medications taken per person was 5.47. Two-thirds (66.66\%) of the residents took medication by themselves, and over $80 \%$ would willingly take it when given by a third party. A large majority (77.77\%) took medications orally, while $15.55 \%$ took them both orally and injected. Over half the residents (57.77\%) presented other physical diseases, and $68.88 \%$ declared to undergo or to have undergone treatment for these diseases.

\section{Patients' Satisfaction with the SRTs}

Individual analysis of each of the 12 SATIS-BR scale items indicated a high degree of satisfaction $164.44 \%$ to $82.22 \%$ of patients reporting maximum scores 4 and 5) regarding various aspects of the SRT services (Table 1). The highest percent of satisfied individuals were

Table 1. Mean Scores and Percent Patient Satisfaction in Responses to the Items of the SATIS-BR Scale.

\begin{tabular}{|c|c|c|c|c|}
\hline \multirow[b]{3}{*}{ Items } & \multirow[b]{3}{*}{$\begin{array}{c}\text { Mean } \\
\text { (Std. Dev) }\end{array}$} & $\begin{array}{l}\text { Dissatisfied } \\
\text { or very } \\
\text { dissatisfied }\end{array}$ & $\begin{array}{l}\text { Fairly } \\
\text { satisfied }\end{array}$ & $\begin{array}{l}\text { Satisfied } \\
\text { or very } \\
\text { satisfied }\end{array}$ \\
\hline & & \multicolumn{3}{|c|}{ Number of respondents (\%) } \\
\hline & & $\begin{array}{l}\text { Answers } \\
1 \& 2\end{array}$ & $\begin{array}{l}\text { Answer } \\
3\end{array}$ & $\begin{array}{l}\text { Answers } \\
4 \& 5\end{array}$ \\
\hline 1. Are you treated with respect and dignity in this house? & $4.36(0.98)$ & $1(2.22 \%)$ & $\begin{array}{r}10 \\
(22.22 \%)\end{array}$ & $34(75.56 \%)$ \\
\hline $\begin{array}{l}\text { 2. When you first talked to the person who brought you to this residence, did you feel that } \\
\text { he/she listened to your history? }\end{array}$ & $4.11(1.28)$ & $5(11.11 \%)$ & $10(22.22 \%)$ & $30(66.67 \%)$ \\
\hline 3. Did the technician that brought you to this house appear to understand your problem? & $4.16(1.21)$ & $3(6.67 \%)$ & $11(24.44 \%)$ & $31(68.89 \%)$ \\
\hline 4. Do you think the caregivers in this house understand the type of help you need? & $4.11(1.13)$ & $2(4.44 \%)$ & $14(31.11 \%)$ & $29(64.44 \%)$ \\
\hline 5. What is your opinion about the help with which this residence provides you? & $4.04(1.41)$ & $6(13.33 \%)$ & $10(22.22 \%)$ & $29(64.44 \%)$ \\
\hline $\begin{array}{l}\text { 6. Are you satisfied with the conversation you had with the technician/ caregivers about } \\
\text { your treatment? }\end{array}$ & $4.42(1.18)$ & $4(8.89 \%)$ & $4(8.89 \%)$ & $37(82.22 \%)$ \\
\hline 7.Do you feel the house staff is helping you? & $4.47(0.89)$ & $0(0.00 \%)$ & $12(26.67 \%)$ & $33(73.33 \%)$ \\
\hline 8. How do you rate the way you were greeted by caregivers/technicians in this house? & $4.44(0.97)$ & $1(2.22 \%)$ & $9(20.00 \%)$ & $35(77.78 \%)$ \\
\hline 9. Do you consider the house staff competent? & $4.36(1.03)$ & $1(2.22 \%)$ & $12(26.67 \%)$ & $32(71.11 \%)$ \\
\hline 10. Do you consider competent the technician and caregivers of this house? & $4.40(0.86)$ & $0(0.00 \%)$ & $11(24.44 \%)$ & $34(75.56 \%)$ \\
\hline 11. Are you satisfied with the comfort and aspect of this house? & $4.44(1.06)$ & $2(4.44 \%)$ & $7(15.56 \%)$ & $36(80.00 \%)$ \\
\hline 12. How do you rate the house facilites (bathroom, kitchen, meals)? & $4.53(0.84)$ & $0(0.00 \%)$ & $10(22.22 \%)$ & $35(77.78 \%)$ \\
\hline
\end{tabular}


found for items 6 "Are you satisfied with the conversation you had with the technician/ caregivers about your treatment?" (82.22\%), item 11 "Are you satisfied with the comfort and aspect of this house?" (80.00\%), and item 8 "How do you rate the way you were greeted by caregivers/ technicians in this house?" (77.78\%). Items for which there were comparatively larger frequencies of dissatisfaction were item 5 "What is your opinion about the help with which this residence provides you?" (13.33\% dissatisfaction) and item 2 "When you first talked to the person who brought you to this residence, did you feel that he/she listened to your story?" (11.11\% dissatisfaction). Those frequencies were nonetheless largely surpassed by frequencies of satisfied individuals.

Mean patients' satisfaction scores were high (>4) not only for the global scale, but also for each of its three component subscales (Table 2). Mean satisfaction measured in the global scale had a score of 4.32 in the 5-point Likert scale, indicating that patients were either satisfied or highly satisfied with the services. The highest degree of satisfaction (score 4,48 ) was for subscale 3 , whereas the lowest score (4.22) was for subscale 1. In spite of the high mean levels of satisfaction found, Kruskal-Wallis tests (Table 2) indicated nevertheless slightly lower levels of satisfaction for the dimension 1 "competence of caregiving staff and their comprehension of the patients' problems" than for dimension $3[p(1-3)=0.015]$. There were no significant differences in satisfaction scores between dimensions 2 and 3 [ $p(2-3)=0.268]$, or between dimensions 1 and 2 [ $p(1-2)=0,145]$.

Univariate analysis was performed for each of the categorical variables comprising the sociodemographic and clinical questionnaires (Table 3). Mean scores and their standard deviations were computed for these categories, and Mann-Whitney two-sample tests were used to compare means of categorical variables. Two clinical variables included in the questionnaire ("Do you currently undergo psychiatric treatment?" and "Have you been subject to treatment in psychiatric hospital") had $100 \%$ of residents responding "Yes", and therefore were not included in the analysis. Results indicated (Table 3 ) that there were no significant differences $(p>0.05)$ between means for any of the categorical variables, and global satisfaction scores were close to or higher than 4 for all categories from all variables (Table 3 ).
Table 2. SATIS-BR Subscale Means, Standard Deviations, and KruskalWallis Tests for Comparisons between Subscales.

\begin{tabular}{|c|c|c|c|c|}
\hline \multirow[b]{2}{*}{ SATIS-BR subscales } & \multirow[b]{2}{*}{ Mean (SD) } & \multicolumn{3}{|c|}{$\begin{array}{l}\text { Multiple comparisons: } \\
\text { Dif }=19.75^{* *}\end{array}$} \\
\hline & & $\operatorname{Dif}(1-2)$ & $\operatorname{Dif}(1-3)$ & $\operatorname{Dif}(2-3)$ \\
\hline $\begin{array}{l}\text { 1. Competence of } \\
\text { caregiving staff and } \\
\text { their comprehen- } \\
\text { sion of the patients' } \\
\text { problems }\end{array}$ & $4.22(0.71)$ & & & \\
\hline $\begin{array}{l}\text { 2. Satisfaction with } \\
\text { the way patients } \\
\text { were received } \\
\text { and helped in the } \\
\text { service }\end{array}$ & $4.42(0.61)$ & 11.74 & & 8.32 \\
\hline $\begin{array}{l}\text { 3. Patient satisfac- } \\
\text { tion with physical } \\
\text { installations and } \\
\text { general comfort } \\
\text { provided by the } \\
\text { service }\end{array}$ & $4.48(0.77)$ & & $20.06^{*}$ & \\
\hline $\begin{array}{l}\text { SATIS-BR global } \\
\text { score }\end{array}$ & $4.32(0.61)$ & & & \\
\hline
\end{tabular}

Note. Bilateral Kruskal-Wallis tests: Chi-square $=6,45 ; \mathrm{d} . \mathrm{f}=2 ; \mathrm{p}=0.04$; Dif(1-2) $=$ mean rank difference between subscales 1 and 2; Dif(1-3) = mean rank difference between subscales 1 and 3; Dif (2-3) ) = mean rank difference between subscales 2 and 3; SD $=$ standard deviation; ${ }^{* *}$ Value obtained from multiple comparisons with the KruskalWallis test.

Spearman correlation coefficients were computed between global satisfaction scores and each one of the continuous demographic and clinical variables present in the questionnaire (Table 4). The correlation coefficients found were close to zero in magnitude, and in no instance were they significant ( $p>0.05$ in all cases) (Table 4).

In spite of the fact that no single variable was clearly associated with SATIS-BR scores, a multiple linear regression approach was implemented, in an attempt to identify groups of variables that could be assumed to be predictors of patients' satisfaction. The stepwise procedure adopted for inclusion/exclusion of variables yielded a significant ( $F$ $=5.040 ; p=0.015)$ multiple regression model in which two variables $\left(\mathrm{X}_{1}, \mathrm{X}_{2}\right)$ were included (Table 5): $\mathrm{X}_{1}=$ Education level ( $0=$ illiterate, $1=$ literate); $X_{2}=$ Do you undergo other types of treaments (other than with medications or occupational therapy)? ( $0=$ No, 1=Yes) (Table 5). 
Table 3. Univariate Analysis of Categoric Sociodemographic and Clinical variables with Respect to Global Satisfaction of Patients with the SRT.

\begin{tabular}{|c|c|c|c|c|}
\hline \multirow[b]{2}{*}{ Categoric variables } & \multirow[b]{2}{*}{ Categories } & \multicolumn{3}{|c|}{$\begin{array}{l}\text { SATIS-BR GLOBAL } \\
\text { SCORE }\end{array}$} \\
\hline & & $\mathbf{N}$ & $\begin{array}{l}\text { Mean (Std. } \\
\text { Deviation) }\end{array}$ & $\mathbf{P}$ \\
\hline \multirow{2}{*}{ Sex } & Female & 24 & $4.24(0.58)$ & \multirow{2}{*}{0.19} \\
\hline & Male & 21 & $4.42(0.66)$ & \\
\hline \multirow{2}{*}{ Comorbidities } & No & 37 & $4.32(0.58)$ & \multirow{2}{*}{0.55} \\
\hline & Yes & 8 & $4.33(0.81)$ & \\
\hline \multirow{2}{*}{$\begin{array}{l}\text { Do you undergo } \\
\text { treatment with } \\
\text { medicaments? }\end{array}$} & No & 4 & $4.61(0.43)$ & \multirow[t]{2}{*}{0.34} \\
\hline & Yes & 41 & $4.29(0.63)$ & \\
\hline \multirow{2}{*}{$\begin{array}{l}\text { Do you undergo } \\
\text { occupational therapy? }\end{array}$} & No & 38 & $4.38(0.54)$ & \multirow{2}{*}{0.56} \\
\hline & Yes & 7 & $4.01(0.94)$ & \\
\hline \multirow{2}{*}{$\begin{array}{l}\text { Do you undergo other } \\
\text { types of treaments? }\end{array}$} & No & 19 & $4.23(0.63)$ & \multirow{2}{*}{0.33} \\
\hline & Yes & 26 & $4.38(0.61)$ & \\
\hline \multirow{2}{*}{$\begin{array}{l}\text { Do you take } \\
\text { medicament by } \\
\text { yourself? }\end{array}$} & No & 12 & $4.22(0.73)$ & \multirow{2}{*}{0.90} \\
\hline & Yes & 30 & $4.34(0.59)$ & \\
\hline \multirow{2}{*}{$\begin{array}{l}\text { Do you take } \\
\text { medicament with } \\
\text { help of other people? }\end{array}$} & No & 1 & $4.17(0.00)$ & \multirow[t]{2}{*}{0.62} \\
\hline & Yes & 37 & $4.29(0.66)$ & \\
\hline \multirow{2}{*}{$\begin{array}{l}\text { What types of } \\
\text { medicament do you } \\
\text { take? }\end{array}$} & Oral & 35 & $4.31(0.63)$ & \multirow{2}{*}{0.84} \\
\hline & $\begin{array}{c}\text { Oral + } \\
\text { Injection }\end{array}$ & 7 & $4.28(0.62)$ & \\
\hline \multirow{2}{*}{$\begin{array}{l}\text { In addition to psychia- } \\
\text { tric disease, do you } \\
\text { have any other physi- } \\
\text { cal disease? }\end{array}$} & No & 15 & $4.34(0.60)$ & \multirow[b]{2}{*}{0.82} \\
\hline & Yes & 26 & $4.34(0.64)$ & \\
\hline \multirow{2}{*}{$\begin{array}{l}\text { Do you undergo } \\
\text { treatment for these } \\
\text { physical diseases? }\end{array}$} & No & 13 & $4.27(0.51)$ & \multirow{2}{*}{0.26} \\
\hline & Yes & 31 & $4.38(0.64)$ & \\
\hline \multirow{2}{*}{ Education } & Illiterate & 18 & $4.23(0.70)$ & \multirow[t]{2}{*}{0.72} \\
\hline & Literate & 27 & $4.38(0.56)$ & \\
\hline \multirow{2}{*}{$\begin{array}{l}\text { Do you live with a } \\
\text { companion? }\end{array}$} & No & 40 & $4.38(0.58)$ & \multirow{2}{*}{0.07} \\
\hline & Yes & 5 & $3.85(0.74)$ & \\
\hline \multirow{2}{*}{$\begin{array}{l}\text { Do you get any money } \\
\text { or income? }\end{array}$} & No & 1 & $4.83(-)$ & 0.32 \\
\hline & Yes & 44 & $4.31(0.62)$ & \\
\hline Income level & $\begin{array}{l}<\text { minimum } \\
\text { wage } \\
\geq \text { minimum }\end{array}$ & 14 & $4.51(0.45)$ & 0.27 \\
\hline & wage & 29 & $4.22(0.69)$ & \\
\hline Are you currently & No & 42 & $4.30(0.63)$ & 0.42 \\
\hline working? & Yes & 3 & $4.67(0.14)$ & \\
\hline Do you perform any & No & 4 & $3.79(1.16)$ & 0.44 \\
\hline in-house activity? & Yes & 41 & $4.37(0.54)$ & \\
\hline $\begin{array}{l}\text { Do you perform any } \\
\text { activities outside the }\end{array}$ & No & 1 & $3.75(-)$ & 0.34 \\
\hline house? & Yes & 44 & $4.33(0.62)$ & \\
\hline Do you have a be- & No & 26 & $4.29(0.61)$ & 0.65 \\
\hline droom all by yours & Yes & 19 & $4.36(0.64)$ & \\
\hline
\end{tabular}

Note. $\mathrm{N}=$ number of respondents; $\mathrm{P}=\mathrm{p}$-value (two-sided Mann-Whitney tests)
Table 4. Univariate Analysis of Continuous Sociodemographic and Clinical Variables with Respect to Global Satisfaction of Patients with the SRT Services.

\begin{tabular}{|c|c|c|c|}
\hline \multirow[b]{2}{*}{ Continuous variable } & \multirow[b]{2}{*}{$\begin{array}{c}\text { Mean } \\
\text { (Std. Deviation) }\end{array}$} & \multicolumn{2}{|c|}{$\begin{array}{l}\text { SATIS-BR GLOBAL } \\
\text { SCORE }\end{array}$} \\
\hline & & (a) $r$ & (b)P \\
\hline Age (years) & $59.4(10.7)$ & -0.293 & 0.051 \\
\hline $\begin{array}{l}\text { Time under psychiatric treatment } \\
\text { (years) }\end{array}$ & $29.5(16.6)$ & -0.130 & 0.40 \\
\hline Years as SRT residents & $9.3(3.0)$ & -0.008 & 0.96 \\
\hline Number of current treatments & $2.7(0.7)$ & -0.021 & 0.89 \\
\hline $\begin{array}{l}\text { Length of the last hospitalization } \\
\text { (years) }\end{array}$ & $23.5(14.0)$ & -0.306 & 0.07 \\
\hline Number of medicaments taken & $5.5(3.8)$ & 0.196 & 0.21 \\
\hline $\begin{array}{l}\text { With how many people do you } \\
\text { share your bedroom? }\end{array}$ & $0.8(0.6)$ & -0.230 & 0.13 \\
\hline
\end{tabular}

Note ${ }^{\left({ }^{(a)} r\right.} \mathrm{r}=$ Spearman correlation coefficients; ${ }^{(b)} \mathrm{p}=\mathrm{p}$-value

Table 5. Multiple Linear Regression of Sociodemographic and Clinical Variables Associated with Satisfaction Scores in Therapeutical Residences: Variables Included by the Stepwise Procedure.

\begin{tabular}{|c|c|c|c|c|c|}
\hline \multirow[b]{2}{*}{ Predictive variables } & \multicolumn{4}{|c|}{ SATIS-BR Global Score } & \\
\hline & Beta & SD & $\mathbf{t}$ & $\mathbf{P}$ & \\
\hline Intercept & 3.805 & 0.191 & 19.969 & $<0.001$ & \\
\hline $\begin{array}{l}\mathrm{X} 1=\text { Education } \\
(0=\text { =illiterate; } 1=\text { literate })\end{array}$ & 0.501 & 0.204 & 2.453 & 0.022 & $\begin{aligned} R 2 & =0.244 \\
F & =5.040\end{aligned}$ \\
\hline $\begin{array}{l}\mathrm{X} 2=\text { Do you undergo } \\
\text { other types of treat- } \\
\text { ments? ( } 0=\mathrm{No} ; 1=\text { Yes) }\end{array}$ & 0.414 & 0.203 & 2.045 & 0.052 & $\begin{array}{c}(p= \\
0.015) \\
D W=1.762\end{array}$ \\
\hline
\end{tabular}

Note. $S D=$ standard deviation; $t=$ values of the $t$ statistics; $P=p$-value; $R^{2}=$ coefficient of determination; $D W=$ Durbin-Watson test

The multiple linear regression model obtained could be expressed as: Satisfaction score $=3.805+$ $0.501 \mathrm{X}_{1}+0.414 \mathrm{X}_{2}$. Adjusted $\mathrm{R}^{2}$ for this regression indicated that these two independent variables were able to explain $24.4 \%$ of the variation among the data (Table 5). The regression indicates that literate patients tend to show satisfaction scores higher $(0.510$ points higher, on a 1 to 5 Likert scale) than those of illiterate patients. Likewise, patients that underwent other types of treatment (other than with medications or occupational therapy) tend to show scores 0.414 higher than those that do not undergo other types of treatment.

Even though this set of two variables was the one that best explained the patient satisfaction scores with the SRTs, the multiple regression model possessed nevertheless a low predictive value (adjusted $R^{2}=0.244$ ). A possible reason for this result can be put down to the fact that satisfaction scores were high (generally larger than 4 in the Likert scale from 1 to 5), as demonstrated 
by the univariate analysis (Tables 3 and 4), with a very narrow range of variation among different levels of each of the variables.

\section{Discussion}

The results of the present study indicate that the psychiatric patients evaluated in the residential services (SRTs) of Barbacena showed a high degree of satisfaction with these services. For each one of the twelve items of the SATIS-BR scale measured with a Likert scale of five points, the overwhelming majority of residents ( $>64 \%$ in all cases) declared themselves satisfied or very satisfied with the services, and only a minority $(<13 \%$ in all cases) declared to be unsatisfied or very unsatisfied, resulting in mean satisfaction scores higher than 4. Global satisfaction score mean was 4.32 in the Likert scale, and in the subscales of the SATIS-BR, mean satisfaction scores were always larger than 4.22 , indicating satisfaction and high satisfaction.

Other than the present work, only one Brazilian study (Jaegger et al., 2004) assessed the satisfaction level of psychiatric patients who were residents in the SRTs. Their authors assessed the global satisfaction score (also through the SATIS-BR scale) of residents in the Instituto Juliano Moreira, Rio de Janeiro-RJ, Brazil. Similarly to our present study with the SRTs in Barbacena-MG, that study (Jaegger et al., 2004) indicated a high global degree of patients' satisfaction with the services (mean score of 4.52 in the 5-point scale). Unfortunately, no results were reported from the SATIS-BR subscales.

In the present study, the highest degrees of patients' satisfaction were found in the SATIS-BR subscale that evaluates physical installations and patient comfort. The physical installations of the SRTs may therefore have been comparatively a major contributor to the global high degree of patient satisfaction.

None of the sociodemographic or clinic variables analyzed separately, whether categorical or continuous, was associated with scores of patients' satisfaction. For the categorical variables, no significant differences in the degree of satisfaction were detected among the categories considered. For the continuous variables, there was no significant correlation with the global score or with any of the subscale scores. The degree of satisfaction was high regardless of sex, age, length of the last hospitalization, length of the SRT stay, education, marital status, income, use of medicaments, types of treatment undergone, or number of additional people in sleeping in the same bedroom, among other variables.

The results allowed however for the identification of sets of variables more closely associated with satisfaction of the Barbacena-MG residents of the SRTs. A multiple linear regression analysis was performed in order to identify variables that, taken as a group, could explain possible differences in the perception of satisfaction among the interviewed patients. Even though the regression indicated that patient satisfaction tends to be higher for patients that were literate and for those that underwent other types of treatment (other than with medications or occupational therapy), the multiple linear model could explain only $24,4 \%$ of the total variation among responses, and had therefore a low predictive value.

Under these circumstances, the high degree of satisfaction observed in this study indicated that the implementation the SRT units lead to satisfactory results, regardless of sociodemographic or clinical patients' characteristics. This result reinforces the SRT model as a general instrument of public policy for social inclusion of a wide range of psychiatric patients.

The present results are similar to those reported by several authors in other countries (Greenfield et al., 2008; Hanrahan, et al., 2001; Hawthorne et al., 2005; Hawthorne et al., 1999; Kasprow et al., 1999; Osborn et al., 2010), in which, in spite of different methodologies, evaluation instruments, previous hospitalization histories and patient populations, no significant differences in the degrees of satisfaction were found among the patient subgroups studied. Wherever differences were detected in those studies, satisfaction scores were higher for patients of residential services.

Other studies in Brazil have also used the SATIS-BR scale as a measure of patient satisfaction (Bandeira et al., 2011; Camilo et al., 2012; Heckert et al., 2007; Kantorski et al., 2009; Silva et al., 2012). However, their objective was to evaluate satisfaction of patients, family members and mental care professionals of the Centers for Psychosocial Attention (CAPS), a nonresidential patient service. It should be noted that in these studies the highest satisfaction scores were found for the dimension that evaluated satisfaction with the professional staff and the lowest satisfaction score for the dimension of services physical structure. In contrast, our SRT study indicated highest satisfaction (score 4.48) in the dimension that evaluated physical installations and patient comfort. 
The high degrees of satisfaction with the SRT demonstrated by the residents in the present study, especially with physical installations/patient comfort, may reflect their past experience with the psychiatric hospital history of Barbacena-MG: pavillions in a precarious state of conservation, excessive number of patients, absence of suitable treatment, lack of remedies, and food scarcity (Vidal et al., 2008). The average period of time spent by the residents in those psychiatric hospitals under such deplorable conditions was 29.5 years - a fact that may have contributed to a high degree of satisfaction with the SRT, under comparatively more adequate facilities. The high degree of patient satisfaction could have resulted from a comparison between their previous expectancies and their actual experiences with the SRT, according to the contrast model of the expectancy approach (Pascoe, 1983), as conceptualized by Ilgen (1971) and Weaver and Brickman (1974).

The current research presents nonetheless some limitations. It is a correlacional study, that is, it was designed to identify factors associated with patient satisfaction, but it could not establish causal relationships among the variables studied. Also, it was a crosssectional study, so that it could not follow up possible changes in the degrees of patient satisfaction along a period of time. A final limitation is that this research dealt with SRT of only one county (Barbacena-MG), a fact that impairs generalization of the results to other counties' residential services. Because of these limitations, new similar studies, with random samples and with the same measurement instrument, would be necessary in order to obtain more general results.

It is rather clear that the SRT experience in Barbacena has nonetheless achieved, at least under the patients' perspective, a degree of success in the process of psychiatric deinstitutionalization. This conclusion indicates that the Barbacena SRT programme is in agreement with suggestions made by Niles (2013) in order to assist mental health professionals and the community at large in implementing programs to assist former patients integrate positively into the community. Deploying qualitative research methods, Franco and van Stralen (2015) reached similar conclusions about the SRT services, pointing out that Back Home Program ('Programa Volta Para Casa', practiced in the city of Belo Horizonte), as well as the psychiatric reform politics, have made possible the deinstitutionalization policy. Positive results with therapeutical residence services were also reported in Northeastern Brazil by Kinker (2017).
Similarly positive deinstitutionalization measures are reported in other countries: in the USA, the YMAYoung Minds Advocacy (2013) points out the positive results brought about by the Community Mental Health Act of 1963 and subsequent policy changes, that helped trigger a major transformation of the public mental health system by shifting resources from large institutions towards community-based mental health programmes, including community living.

In spite of the positive results achieved by therapeutical residence services and other deinstitutionalization programmes, there is some criticism about its effectiveness towards patients with severe mental illnesses. Davis, Fulginiti, Kriegel and Brekke (2012) indicated that the current U.S. decentralized community-based model of mental health care has generally benefited middle-class individuals with less severe disorders, while those with serious and persistent mental illness, with the greatest need, often fare the worst - a statement backed up by Pollack (2013). Underfunding by local and federal governments is reported by many authors (Davis et al., 2012; Pollack, 2013; Yohanna, 2013) as a probable cause of this limited success.

In Brazil, even though socioeconomic statistics on mental health patients is scarce, studies with patients discharged from psychiatric hospitalization and their caregivers (Cardoso \& Frari-Galera, 2011), and with CAPS patients (Mangualde et al., 2012) indicated a picture of predominantly low income. The Barbacena SRT patients in our study were overwhelmingly illiterate or barely literate (>80\%), held no formal jobs (>90\%) and whatever income they had came from public funds. The underfunding issue is therefore particularly critical for therapeutic residence programmes in Brazil, since the initial expectation that community-based health services would be cheaper than hospital-based services do not necessarily turn out to be true (Yohanna, 2013).

\section{References}

Andreoli, S. B. (2007). Serviços de Saúde Mental no Brasil. In M. F Mello, A. A. F Mello, \& R. Kohn (Eds.), Epidemiologia da saúde mental no Brasil. (pp. 85-100). Porto Alegre: Artmed; 2007.

Bandeira, M., Ishara, S., \& Zuardi, A.W. (2007). Satisfação e sobrecarga de profissionais de saúde mental: validade de construto das escalas SATIS-BR e IMPACTO-BR. Jornal Brasileiro de Psiquiatria, 56(4), 280-286. doi: 10.1590/S0047-20852007000400007

Bandeira, M., \& Silva, M. A. (2012). Escala de Satisfação dos Pacientes com os Serviços de Saúde Mental (SATIS-BR): estudo de validação. Jornal Brasileiro de Psiquiatria, 61(3), 124-132. doi: 10.1590/ S0047-20852012000300002 
Bandeira, M., Silva, M. A., Camilo, C. A., \& Felicio, C. M. (2011). Satisfação de familiares de pacientes psiquiátricos com os serviços de saúde mental e seus fatores associados. Jornal Brasileiro de Psiquiatria, 60, 284-293. doi: 10.1590/S0047-20852011000400009

Bandeira, M., Pitta, A. M. F., \& Mercier, C. (2000). Escala de avaliação da satisfação dos usuários em serviços de saúde mental: SATIS-BR. Jornal Brasileiro de Psiquiatria, 49, 293-300.

Barroso, S., Bandeira, M., \& Nascimento, E. (2007). Sobrecarga de familiares de pacientes psiquiátricos atendidos na rede pública. Revista de Psiquiatria Clínica, 34, 270-277. doi: 10.1590/ S0101-60832007000600003

Camilo, C. A., Bandeira, M., Leal, R. M. A. C., \& Scalon, J. D. (2012). Avaliação da satisfação e sobrecarga em um serviço de saúde mental. Cadernos de Saúde Coletiva, 20, 82-92. Retrieved from http://iesc.ufrj.br/cadernos/images/csc/2012_1/artigos/CSC_ v20n1_82-92.pdf

Cardoso, L., \& Frari-Galera, S. A. (2011). O cuidado em saúde mental na atualidade. Revista da Escola de Enfermagem da USP, 45(3), 687-691. doi: 10.1590/S0080-62342011000300020

Contandriopoulos, A. P. (2006). Avaliando a institucionalização da avaliação. Ciência e Saúde Coletiva, 11(3), 705-711. doi: 10.1590/ S1413-81232006000300017

Davis, L., Fulginiti, A., Kriegel, L., \& Brekke, J. S. (2012). Deinstitutionalization? Where have all the people gone? Current Psychiatry Reports, 14(3), 259-269. doi: 10.1007/ s11920-012-0271-1

Delgado, P. G., Schechtman, A., Weber, R., Amstalden, A. F., Bonavigo, E., Cordeiro, F., ..., Grigolo, T. (2007). Reforma psiquiátrica e política de saúde mental no Brasil. In M. F. Mello, A. A. F. Mello, \& R. Kohn (Eds.), Epidemiologia da saúde mental no Brasil. (pp. 39-84). Porto Alegre: Artmed.

Donabedian, A. (1966). Evaluating the quality of medical care. Milbank Memorial Fund Quarterly, 44, 166-203. doi: 10.1111\%2Fj.1468-0009.2005.00397.x

Donabedian, A. (1990). The seven pillars of quality. Archives of Pathology Laboratory Medicine, 114, 1115-1118.

Franco, R. F., \& van Stralen, C. J. (2015). Desinstitucionalização psiquiátrica: do confinamento ao habitar na cidade de Belo Horizonte. Psicologia e Sociedade, 27(2), 312-321. doi: 10.1590/1807-03102015v27n2p312

Furtado, J. P. (2006). Avaliação da situação atual dos Serviços Residenciais Terapêuticos no SUS. Ciência e Saúde Coletiva, 11, 785-795. doi: 10.1590/S1413-81232006000300026

Greenfield, T. K., Stoneking, B. C., Humphreys, K., Sundby, E., \& Bond, J. (2008). A randomized trial of a mental health consumer-managed alternative to civil commitment for acute psychiatric crisis. American Journal of Community Psychology, 42(1-2), 135-144. doi: 10.1007/ s10464-008-9180-1

Hanrahan, P., Luchins, D. J., Savage, C., \& Goldman, H. (2001). Housing satisfaction and service use by mentally ill persons in community integrated living arrangements. Psychiatric Services, 52, 12061209. doi: 10.1176/appi.ps.52.9.1206

Hawthorne, W. B., Green, E. E., Gilmer, T., Garcia, P., Hough, R. L., Lee, M., ... Lohr, J. B. (2005). A randomized trial of short-term acute residential treatment for veterans. Psychiatric Services, 56, 1379-1386. doi: 10.1176/appi.ps.56.11.1379

Hawthorne, W. B., Green, E. E., Lohr, J. B., Hough, R., \& Smith, P. G. (1999). Comparison of outcomes of acute care in short-term residential treatment and psychiatric hospital setting. Psychiatric Services, 50, 401-406. doi: 10.1176/ps.50.3.401

Heckert, U., Teixeira, L. S., \& Trindade, A. S. (2007). Avaliação da satisfação dos usuários do Centro Regional de Referência em Saúde Mental (CRRESAM) da região central de Juiz de Fora, MG. HU Revista, 32, 15-19. Retrieved from https://hurevista.ufjf.emnuvens. com.br/hurevista/article/view/6

Ilgen, D. R. (1971). Satisfaction with performance as a function of the initial level of expected performance and the deviation from expectations. Organizational Behavior and Human Performance, 6, 345361. doi: 10.1016/0030-5073(71)90022-5

Jaegger, R. C., Guitton, A. P., Lyrio, J. M., Santos, M. M., Freitas, R. C. O., Gonçalves, S. R., \& Legay, L. F. (2004). A Experiência de morar fora: avaliação da satisfação de usuários em um serviço de saúde mental. Cadernos de Saúde Coletiva, 12, 26-39. Retrieved from http://www.cadernos.iesc.ufrj.br/cadernos/images/csc/2004_1/ artigos/cad20041_jaegger.pdf

Kantorski, L. P., Jardim, V. R., Wetzel, C., Olschowsky, A., Schneider, J. F., Heck, R. M., ... Saraiva, S. S. (2009). Satisfação dos usuários dos centros de atenção psicossocial da região Sul do Brasil Revista de Saúde Pública, 43(suppl 1), S29-S35. doi: 10.1590/ S0034-89102009000800006

Kasprow, W. J., Frisman, L., \& Rosenheck, R. A. (1999). Homeless veterans' satisfaction with residential treatment. Psychiatric Services, 50(4), 540-545. doi: 10.1176/ps.50.4.540

Kinker, F. S. (2017). Um hospício em crise: imagens de uma experiência de desinstitucionalização. Interface (Botucatu), 21(60), 189-198. doi: 10.1590/1807-57622016.0163

Mangualde, A. A. S.; Botelho, C. C.; Soares, M. R.; Costa, J. F.; Junqueira, C. M.; \& Vidal, C. E. L. (2012) Perfil epidemiológico dos pacientes atendidos em um Centro de Atenção Psicossocial Mental, 19, 235-248. Retrieved from http://pepsic.bvsalud.org/scielo.php?script=sci_arttext\&pid=S1679-44272012000200006\&lng $=$ pt\&tlng=pt

Ministério da Saúde. (2004). Caderno do Programa Nacional de Avaliação dos Serviços de Saúde - PNASS. Edição 2004/2005. Brasília, DF.

Ministério do Desenvolvimento Social e Combate à Fome. (2014). Assistência Social. Benefícios Sociais. Benefício de Prestação Continuada. Brasilia, DF: Author. Retrieved from http://www.mds. gov.br/assistenciasocial/beneficiosassistenciais/bpc

Niles, C. (2013). Examining the deinstitutionalization movement in North America. Health Tomorrow, 1, 54-83.

Organização Mundial de Saúde. (1998). CID-10: Classificação Internacional de Doenças e Problemas Relacionados à Saúde (10a. ed). São Paulo: Edusp.

Osborn, D. P. J., Lloyd-Evans, B., Johnson, S., Gilburt, H., Byford, S., Leese, M., \& Slade, M. (2010). Residential alternatives to acute inpatient care in England: satisfaction, ward atmosphere and service user experiences. The British Journal of Psychiatry, 197, 41-45. doi: 10.1192/bjp.bp.110.081109

Pascoe,G. C. (1983). Patient satisfaction in primary health care: a literature review and analysis. Evaluation and Program Planning, 6(3-4), 185-210. doi:10.1016/0149-7189(83)90002-2

Piat, M., Lesage, A., Boyer, R., Dorvil, H., Couture, A., Grenier, G., \& Bloom, D. (2008). Housing for persons with serious mental illness: 
Psychiatric patients' satisfaction in the therapeutic residence services

consumer and service provider preferences. Psychiatric Services, 59(9), 1011-1017. doi: 10.1176/appi.ps.59.9.1011

Pollack, H. (2013). What happened to U.S. mental health care after deinstitutionalization? The Washington Post: Author. Retrieved from https://www.washingtonpost.com/news/wonk/wp/2013/06/12/ what-happened-to-u-s-mental-health-care-after-deinstitutionalization/?utm_term=.11eeb96f3edc

Ruggeri, M. (1994). Patients' and relatives' satisfaction with psychiatric services: the state of the art of its measurement. Social Psychiatry and Psychiatric Epidemiology, 29(5), 212-227. doi: 10.1007/ BF00796380

Ruggeri, M. (2010) Satisfaction with mental health services. In G. Thornicroft \& M. Tansella (Eds.), Mental health outcome measures. (pp. 99-115). London: RCPsych Publications.

Silva, M. A. S.; Bandeira, M., Scalon, J. D., \& Quaglia, M. A. C. (2012). Satisfação dos pacientes com os serviços de saúde mental: a percepção de mudanças como preditora. Jornal Brasileiro de Psiquiatria, 61(2), 64-71. doi: 10.1590/S0047-20852012000200002

Thornicroft, G., \& Tansella, M. (2005). Growing recognition of the importance of involvement in mental health service planning and evaluation. Epidemiologia e Psichiatria Sociale, 14, 1-3. doi: 10.1017/S1121189X00001858

Thornicroft, G., \& Tansella, M. (2010). Saúde Mental da população e cuidado comunitário. In G. Thornicroft \& M. Tansella (Eds.), Boas práticas em saúde mental comunitária. (pp. 6-19). Barueri: Manole.

Vidal, C. E. L., Bandeira, M., \& Gontijo, E. D. (2008). Reforma psiquiátrica e serviços residenciais terapêuticos. Jornal Brasileiro de Psiquiatria, 57, 70-79. doi: 10.1590/S0047-20852008000100013

Weaver, D., \& Brickman, P. (1974). Expectancy, feedback and disconfirmation as independent factors in outcome satisfaction. Journal of Personality and Social Psychology, 30, 420-428. doi: 10.1037/ h0036854

World Health Organization. (1996). WHO-SATIS consumer's and caregivers' satisfaction with mental health services: a multisite study. Geneva: Division of Mental Health.

Young Minds Advocacy. (2013). The Community Mental Health Act of 1963: Still Pursuing the Promise of Reform Fifty Years Later. YMA: Author. Retrieved from https://www.ymadvocacy.org/ the-community-mental-health-act-of-1963

Yohanna, D. (2013). Deinstitutionalization of people with mental illness: causes and consequences. Virtual Mentor, 15(10), 886-891. doi: 10.1001/virtualmentor.2013.15.10.mhst1-1310

Rafael Gustavo Maluf, Mestre em Psicologia pela Universidade Federal de São João Del Rei (UFSJ), é Professor do curso de pósgraduação em Terapia Cognitiva-Comportamental da Universidade

José do Rosário Vellano (Unifenas) campus Varginha. Endereço para correspondência: Alameda das Acácias, 268, Jardim das Palmeiras, Lavras, Minas Gerais. Telefone para contato: (35) 38216665; (35) 988446004. E-mail: rafmaluf@gmail.com

Marina de Bittencourt Bandeira, Doutor em Psicologia, Université de Montréal, (U.DEM.), Canadá, Pós-Doutorado na McGill

University - Centre de Recherche Psychosociale (WHO, MCGILL),

Canadá, Pós-Doutorado no Centre de Recherche Fernand Seguin Université de Montréal (CRFS - U.DEM.), Canadá, é Professor titular na Universidade Federal de São João Del Rei (UFSJ). E-mail: bandeira@ufsj.edu.br

Daniela Carine Ramires de Oliveira, Doutor em Estatística e Experimentação Agropecuária pela Universidade Federal de Lavras (UFLA), é Professor Adjunto na Universidade Federal de São João Del Rei (UFSJ). E-mail: ramires.daniela@gmail.com 